\title{
Teaching Formulaic Sequences in an English- Language Class: The Effects of Explicit Instruction Versus Coursebook Instruction
}

\section{Duyen Le-Thi, Michael P. H. Rodgers, E Ana Pellicer-Sánchez}

This study investigates the relative effectiveness of different teaching approaches on the learning of formulaic sequences. Three comparisons were made in this study: the effects of explicit teaching of formulaic sequences versus teaching embedded in traditional coursebook instruction, the effects of the degree of salience of the sequences in the coursebook on learning, and the effects of explicit teaching of formulaic sequences with context versus teaching without context. Sixtynine formulaic sequences occurring in an English as a Foreign Language (EFL) coursebook were selected for the study. The participants were 60 low-proficiency university students majoring in technology in Vietnam. Participants were quasirandomly assigned to one of three groups: control, no-context learning, and sentence-context learning. Learning was measured by two multiple-choice tests of receptive knowledge of form and meaning. Findings indicated that although explicit instruction was effective, the degree of salience in traditional coursebook instruction had no significant effects on learning formulaic sequences. Explicit teaching combined with incidental exposure to formulaic sequences in the coursebook was superior to the traditional coursebook instruction approach in the classroom setting. Furthermore, the results from explicit instruction with context sentences did not differ significantly from those of instruction without context. Explanations for the findings and pedagogical applications are offered.

Cette étude porte sur l'efficacité relative de différentes approches pédagogiques visant l'enseignement de formules. Trois comparaisons ont été effectuées: les effets de l'enseignement explicit de formules comparativement à l'enseignement traditionnel dans le cadre de cours basés sur un manuel de classe; les effets sur l'apprentissage du degré de pertinence des formules du manuel; et les effets de l'enseignement explicit de formules avec un contexte comparativement à l'enseignement sans contexte. D'un manuel d'anglais langue étrangère, on a tiré soixante neuf formules pour notre étude. Soixante étudiants à l'université, avec un bas niveau de compétence et poursuivant une majeur en technologie au Vietnam, ont participé à l'étude. Les participants ont été assignés, de façon quasi-aléatoire, à un de trois groupes: témoin, apprentissage sans contexte et apprentissage avec contexte. L'apprentissage a été mesuré avec deux tests à choix multiples portant sur les connaissances réceptives de la forme et du sens. Les résultats indiquent que si l'enseignement explicit est efficace, le degré de pertinence de l'enseignement traditionnel avec un manuel n'a eu aucun effet significatif sur l'apprentissage des formules. L'enseignement explicit combiné à l'exposition accidentelle aux for- 
mules dans le manuel de classe était supérieur à l'enseignement traditionnel basé sur un manuel de classe. De plus, il n'y a pas eu de différences marquées entre les résultats de l'enseignement explicit avec un contexte et ceux de l'enseignement sans contexte. Nous offrons des explications pour les résultats ainsi que des applications pédagogiques.

KEYWORDS: EFL, instructed SLA, L2 pedagogy, explicit teaching, formulaic sequences, context

There has long been interest in applied linguistics research on the value of learning formulaic language (Ellis, 2012). Knowledge of formulaic sequences can provide advantages to language learners in a number of ways. First, it may help improve comprehension (Nation, 2013; Schmitt, 2010) as language processing is sensitive to sequence information (Ellis, 2002). When presented with input, language users that have large amounts of sequences accessible as single units in their mental lexicon (Sinclair, 1991; Wray, 2002) can make use of these single units to process it, thereby comprehending the input quicker. Second, it can contribute to smoothness in communication (Pawley \& Syder, 1983; Schmitt, 2010; Wood, 2002). It is claimed that to be fluent in a second language, a large repertoire of formulaic sequences is essential (Biber, Conrad, \& Cortes, 2003; Nattinger \& DeCarrico, 1992; Schmitt \& Carter, 2004; Wray, 2002). However, although some studies show that some learners may have knowledge of formulaic sequences (e.g., Schmitt, Dörnyei, Adolphs, \& Durow, 2004; Spöttl \& McCarthy, 2004), other research suggests that many learners have a limited command of formulaic sequences (e.g., Durrant \& Schmitt, 2009). For these reasons, "instructed SLA should include the teaching of formulaic sequences as a featured component" (Dörnyei, 2009, p. 302). However, there appears to be little understanding of how best to teach formulaic language in L2 pedagogy (Coxhead, 2015). The present study attempts to address this concern.

\section{Background}

\section{Formulaic Sequences}

Many different terms have been used to describe formulaic language, such as sentence stems (Pawley \& Syder, 1983), lexical phrases (Nattinger \& DeCarrico, 1992), chunks (Ellis, 1996), and multiword items (Nation, 2013). Wray (2002) and Schmitt and Carter (2004) agreed on the term formulaic sequences. Wray defines a formulaic sequence as

a sequence, continuous or discontinuous, of words or other meaning elements, which is, or appears to be, prefabricated: that is, stored and retrieved whole from memory at the time of use, rather than being subject to generation or analysis by the language grammar. (2002, p. 9) 
This definition is considered to be quite open (Ellis, 2012) because it covers various types of formulaic language (e.g., collocations, idioms, phrasal verbs, binomials, etc.).

As mentioned above, knowledge of formulaic sequences has value for language learners. Empirical evidence suggests that it allows for ease of language processing (Conklin \& Schmitt, 2008), thereby promoting reading comprehension (Kremmel, Brunfaut, \& Alderson, 2015), fluency in communication (Schmitt, Jiang, \& Grabe, 2011; Wood, 2006), and improved performance on proficiency tests (Koosha \& Jafarpour, 2006). Yet despite this, learners typically have limited knowledge of formulaic language. For example, when surveyed on knowledge of the form and meaning of collocations, learners in EFL contexts were shown to know only 33\% (Macis \& Schmitt, 2016) or 56.6\% (González-Fernández \& Schmitt, 2015) of those tested. Although advanced learners may have better receptive knowledge of formulaic sequences, they have a tendency not to use them effectively (Siyanova \& Schmitt, 2008). Instead, they tend to overuse, underuse, or misuse them (Paquot \& Granger, 2012). Learners either rely on a narrow range of high-frequency items (Durrant \& Schmitt, 2009), turn to using non-native-like patterns translated from their first language (Yamashita \& Jiang, 2010), or only use a small number of familiar items that they feel safe and confident using (Granger, 1998). Thus, formulaic sequences seem to be an ideal unit for teaching (Nattinger \& DeCarrico, 1992). However, it is still an open question as to how to teach formulaic sequences effectively in language classes.

\section{Incidental and Explicit Learning of Words and Formulaic Sequences}

Approaches to teaching formulaic sequences can be based on evidence from vocabulary learning research because they are considered as a type of lexeme (Schmitt \& Carter, 2004). Nation and Newton (1997) offer a useful distinction between two main approaches to vocabulary teaching in traditional language classes: direct and indirect. In the former approach, teachers pay direct attention to teaching new items through activities such as doing vocabulary exercises (e.g., matching words with definitions), vocabulary testing, and rote learning. Through direct teaching in the classroom, explicit learning may occur. In the latter, vocabulary items are introduced as part of the input. Instruction can include vocabulary learning in meaning-based activities such as information gaps, group work, listening, or reading activities. In this way, target vocabulary can be incidentally learned. Nation and Newton also note that these are not two alternative approaches in language classes, but they may be complementary to each other. These two teaching approaches lead to two different learning modes: incidental and explicit (Schmitt, 2000). Indirect teaching may lead to incidental learning of vocabulary, by which lexical items are learned as a byproduct of meaning-focused activities such as reading, listening, or speaking. Direct teaching leads to explicit learning of vocabulary, with learners deliberately directing their attention toward lexical 
items (Schmitt, 2000). Explicit learning from direct instruction includes activities such as learning from word cards, using translation, using dictionaries, teacher explanation, or doing exercises (Nation, 2013).

Encountering a word many times in input can lead to incidental learning of that word (Nagy \& Anderson, 1984). Substantial research has suggested the effects of frequency of occurrence on incidental learning from reading (e.g., Pellicer-Sánchez, 2016; Pellicer-Sánchez \& Schmitt, 2010; Waring \& Takaki, 2003; Webb, 2007a) and listening (e.g., van Zeeland \& Schmitt, 2013; Vidal, 2011). There is also potential for incidental learning of vocabulary from watching movies (Webb \& Rodgers, 2009a) or television programs (Webb \& Rodgers, 2009b). Overall, findings suggest words encountered from three to six times in short contexts (i.e., sentences or passages) may be learned significantly better than those encountered once or twice. However, 8 to 10 encounters may be needed for some aspects of word knowledge to be incidentally learned from longer reading texts such as grade readers or authentic novels.

Research also suggests that explicit activities can foster the learning of words (e.g., Laufer \& Girsai, 2008; Peters, 2012; Webb, 2005, 2007b). Explicit learning of words in isolation or after meaning-focused tasks tends to be more effective than explicit learning integrated into meaning-focused tasks (Laufer, 2006; Laufer \& Rozovski-Roitblat, 2011). This may be because in the former, words can be treated as the objects of study while in the latter, they can be regarded as tools for task performance (Laufer, 2006). Furthermore, repetition and retrieval are linked to explicit learning of words. For example, Peters (2014) found 5 repetitions superior to 1 for recall of word form. Nakata (2016) found that 5 and 7 retrieval times were significantly more effective than 1 and 3 times in terms of form and meaning recall. Overall, according to Schmitt (2008), although explicit learning of words tends to be more effective than incidental learning in terms of the extent and rate of learning, retention, and production, explicit teaching of vocabulary does not appear to be a major component of language classes.

Despite the considerable empirical evidence for the incidental learning of single-word items, very few studies have so far explored the effectiveness of different modes of exposure for the incidental learning of formulaic sequences. Durrant and Schmitt (2010) provided evidence for the incidental learning of collocations encountered once or twice in sentence contexts. Items encountered twice were learned better than those encountered once in a form recall test. Webb, Newton, and Chang (2013) suggested positive effects of reading-while-listening on the incidental learning of collocations. Learners learned form and meaning of the target items when encountering them 5, 10, and 15 times from reading-while-listening to a grade reader. Pellicer-Sánchez (2017) also found significant incidental learning of adjective-pseudoword collocations appearing 4 and 8 times in a short story.

Previous research has also shown the possibility of learning formulaic sequences explicitly. Teaching 30 idioms over 6 weeks, Alali and Schmitt (2012) 
found that the participants could recognize the form and meaning of almost all idioms taught, but could recall only $8 \%$ of them. Zyzik (2011) found significant learning in both recognition and production tasks after teaching 38 Spanish idioms over 10 sessions. To teach 65 formulaic sequences over 10 weekly sessions, Al Hassan and Wood (2015) devoted $80 \%$ of class time to presentation and practice and $20 \%$ to uncontrolled production. They found that the participants could use significantly higher numbers of formulaic sequences in their writing posttest than in the pretest. Research has also suggested that frequency of exposure seems to have an effect on the explicit learning of formulaic sequences. For example, Peters (2014) and Webb and Kagimoto (2009) found significantly better learning when explicit encounters increased.

\section{Contextualized Learning of Words}

While research suggests that explicit learning is effective for the acquisition of vocabulary, a further issue is whether explicit learning with sentence context is better than without. On one hand, it is argued that vocabulary should be taught in context because when a new word is naturally associated with other words in that context, it may be easier to be learned (Taylor, 1982). Similarly, when learning a word with a sentence, learners can learn other aspects of knowledge, such as its part of speech or the places it usually occurs in a sentence (Webb, 2007b). On the other hand, learning words without context may be less demanding and more effective because the form-meaning link is straightforward (Seibert, 1930) and the words become the focus of study (Laufer, 2006).

However, research has presented inconsistent conclusions regarding the differences in learning words with and without context. In an early study, Seibert (1930) had one group read aloud a list of 12 words with translations while the other read them with context sentences. The recall tests were in both sentence-context and no-context conditions. The results suggested that learning the words in isolation was better than with context. Similar results were found by Golonka et al. (2015). Their learners were presented with 60 target words learned across six sessions. They found that in the immediate posttest, learning words with no context was better than with sentence context. Other studies have failed to observe a difference between the learning of words with or without context. For example, Pickering (1982) presented 20 words and their translations to one group, and with sentence context to the other. The participants learning words in isolation took a decontextualized test of form and meaning recall while the other was given a similar test but with context sentences. The findings indicated no differences in learning words in the two conditions. In a study by Dempster (1987), one group learned 38 words in isolation, another learned each word with one sentence, and a third group learned with three sentences. The results from a decontextualized meaning recall test revealed no differences in learning across the 
three conditions. Similarly, in Laufer and Shmueli's study (1997), one group studied 20 target words with either L1 definitions, L2 definitions, or synonyms; a second group studied the same materials but read the sentence context; and a third group studied the words with more extended contexts. A decontextualized form and meaning recognition test was given, and the results revealed no significant differences in learning. Webb (2007b) used 20 nonsense words matched with L1 meanings of 20 low-frequency English words as target items. Each group was given a list of word pairs either with or without sentences. All target words in the sentences were in bold and underlined. Findings suggested no differences in learning between the two groups. The potential advantage of learning words in sentence contexts seems to be modulated by learners' level of proficiency. Griffin (1992) asked two groups of learners to study lists of 20 target words with or without sentence context. Learning in both groups was measured by a test of form-meaning link. The findings suggested that for advanced learners, learning with sentence context was more effective than without, while for low-proficiency learners no difference was found.

In addition to the conflicting evidence for the role of context in vocabulary learning provided by the aforementioned studies, they all investigated single words. Thus, the effect of context on the learning of formulaic sequences is still unknown. It can be hypothesized that learning formulaic sequences with context sentences would be better than without. Presenting formulaic sequences in sentence contexts could help learners to understand the semantic constraints of their use. Formulaic sequences vary in their degree of fixedness. Although some are fixed groups of words (e.g., on the other hand), others have slots in which different words can be filled (e.g., take _- for granted). The words that can fill these slots are often limited to those with particular meaning senses (Schmitt, 2010). For example, the formulaic sequence manage to _ is used to mean to "succeed in doing or dealing with something, especially something difficult" (Manage, Cambridge Dictionary, n.d.). The verb that can be used in the slot should convey a degree of achievement. Therefore, it sounds natural to say She managed to overcome the challenges, but strange to say She managed to fail the exam. The use of sentence contexts in the teaching of formulaic sequences could help learners to understand these constraints. However, empirical evidence is yet to support this hypothesis.

\section{Teaching Formulaic Sequences}

The studies reviewed above explored the effects of different types of exposure on the incidental and explicit learning of formulaic sequences and were conducted in relatively tightly controlled conditions. Although they provided useful insights into the effectiveness of different approaches, their ecological validity might be limited, as in real classroom contexts teaching usually includes a combination of direct and indirect activities that lead to both incidental and explicit learning opportunities. 
Simple exposure to meaning-focused input might be insufficient for L2 adult learners to learn language features (DeKeyser \& Juffs, 2005). Thus, in instructed SLA, although incidental learning of linguistic features should be balanced with explicit learning activities, the challenge is how to maximize the cooperation of these two learning mechanisms (Dörnyei, 2009).

There have been a number of studies on formulaic sequences that have investigated explicit teaching embedded into traditional language classes that included both incidental and explicit learning opportunities. Jones and Haywood (2004) taught 74 target items selected on a frequency basis to ESL students. The treatment included explicit activities added to reading and writing tasks. The academic texts were also adapted to increase the occurrences of the target items. They found that although participants in the treatment group showed greater awareness of the sequences in reading texts than a control group, an end-of-course essay revealed no evidence of greater use of the target items than that of the control. Schmitt et al. (2004) taught intermediate ESL learners target items selected based on three criteria: degree of frequency, connection with academic discourse, and usefulness to learners. They found significant learning of the form and meaning of the target items from incidental exposure in the reading materials and explicit vocabulary activities. In an EFL program, Boers, Eyckmans, Kappel, Stengers, and Demecheleer (2006) asked advanced learners to listen to audios or videos for comprehension, and then do several gap-fill exercises created based on the transcripts and highlight formulaic sequences in the reading texts or transcripts. Learning gains were measured by a speaking task. Results showed that learning by the treatment group was superior in terms of sequences produced to a control.

\section{Research Questions}

Taken as a whole, the previous research into the teaching of formulaic sequences has shown that they can be learned through both incidental and explicit approaches. However, there are few studies on the efficient combination of these approaches. There has also been a lack of studies utilizing classroom-based research investigating the learning of formulaic sequences integrated into an existing course that combines a variety of approaches. With this in mind, the present study was designed to answer the following research questions:

1. Is the explicit teaching of formulaic sequences more effective than traditional coursebook instruction? ${ }^{1}$

2. Is there a difference in learning gains of knowledge of formulaic sequences explicitly taught with and without context?

3. Does the degree of salience of the formulaic sequences embedded in the traditional coursebook instruction have an effect on learning gains? If so, how does the learning of incidentally encountered items compare to that of the explicitly taught items? 


\section{Methodology}

\section{Participants}

A total of 76 Vietnamese university EFL students participated in this study. The data of 16 participants were removed from analysis because they were not present during one of the testing or learning sessions. This left the data of 60 participants ( 47 males and 13 females) for analysis. Their ages ranged from 19 to 21 , though one was 31 years old $(M=19.4, S D=1.6)$. They were taking part in the last level of a five-level general English language course before starting their majors in Information Technology and Software Engineering. Thus, all participants received the same traditional coursebook instruction and were also assigned to one of three groups that varied in presence of or the type of explicit instruction. They were quasi-randomly assigned into three groups (control $=20$, no-context $=21$, sentence-context $=19$ ). At the beginning of the study, participants completed the Vocabulary Levels Test (Schmitt, Schmitt, \& Clapham, 2001). The results suggest they were at a low proficiency level because the mean scores of the test of the first 2,000 word families was $22.13(S D=3.8)$. The three groups did not differ significantly in terms of vocabulary level $(F(2,54)=.374, p=.69)$. Table 1 shows the scores of Vocabulary Levels Test 2000 for the three groups.

Table 1

Scores on Vocabulary Levels Test 2000

\begin{tabular}{lrrrr}
\hline Group & Min & Max & $M$ & $S D$ \\
\hline Control & 14 & 29 & 21.44 & 4.08 \\
No-context & 17 & 29 & 22.50 & 2.78 \\
Sentence-context & 13 & 29 & 22.32 & 4.63 \\
\hline
\end{tabular}

\section{Materials}

\section{Coursebook}

The coursebook used for the program of study was the student book and workbook of Summit 2 (Saslow \& Ascher, 2006), the upper-intermediate level in the multilevel series of general English by Pearson Longman. This series aims to prepare the students with an integrated set of skills for global communication. The total word count for the coursebook was 81,152 running words.

\section{Target Items}

Given that most experimental research on formulaic sequences has focused on either collocations or idioms, the present study investigated another type: phrasal expressions. These are defined as nontransparent multiword expressions. The reference for this type of formulaic sequence was 505 phrasal 
expressions compiled in the PHRASE List by Martinez and Schmitt (2012), which, according to the authors, might cause trouble for learners at the receptive level. We selected 69 formulaic sequences (see Appendix A) co-occurring in the coursebook and in the PHRASE List for the study. This item selection method was carried out so that the research was pedagogically relevant to the participants and the recommendation that formulaic sequences based on a frequency list be included in L2 pedagogical syllabuses was satisfied (Garnier \& Schmitt, 2014; Martinez \& Schmitt, 2012; Simpson-Vlach \& Ellis, 2010). Thus, all participants were exposed to these 69 items in the coursebook. Fifty-six of these were selected as experimental items, appearing both in the coursebook and the explicit teaching treatments. The remaining 13 items were control items that were found in the coursebook content but were not part of the explicit teaching treatments. While it cannot be completely guaranteed that all parts of the textbook, and subsequently all the target items, were covered by the teachers in the three groups, it is highly likely that they were. The reason for this is that the course was designed to be an intensive English-preparation program with a tightly controlled syllabus. This meant that the teachers had strict guidelines about what they were to teach in each 90-minute session (i.e., approximately two pages of the textbook each time) such that the entire textbook and associated materials were accounted for by the end of the course.

The coursebook was carefully inspected to determine the type of input and activities in which the experimental and control items appeared and the number of times they occurred (see Table 2). Out of the 56 experimental items, 48 occurred in meaning-focused input only (e.g., texts for reading and listening comprehension and instructions for tasks in the coursebook) that could lead to incidental learning opportunities, and 8 in both meaning-focused input and exercises (e.g., vocabulary instruction activities that occasionally included formulaic language). Among the 13 control items, 8 occurred in meaning-focused input only, and 5 in both meaning-focused input and

Table 2

Frequency of Exposure in the Coursebook Materials of the Experimental and Control Items

\begin{tabular}{lrr}
\hline $\begin{array}{l}\text { Experimental sequences (appearing in both } \\
\text { coursebook and explicit teaching treatment) }\end{array}$ & $n=48$ & $n=8$ \\
Frequency of exposure in meaning-focused input & $1-9$ & $1-7$ \\
Frequency of exposure in coursebook exercises & 0 & $1-5$ \\
\hline Control sequences (appearing only in coursebook) & $n=8$ & $n=5$ \\
Frequency of exposure in meaning-focused input & $1-6$ & $2-6$ \\
Frequency of exposure in coursebook exercises & 0 & $2-3$ \\
\hline
\end{tabular}

Note. $n=$ numbers of items. 
exercises. Appendix C provides an example of how two target items were presented in vocabulary exercises in the coursebook.

To examine the possible effect that the level of prominence of the formulaic sequences in the coursebook had on their learning in the experimental conditions (no-context group and sentence-context group), the target items were classified by their salience in the coursebook. Based on the information provided in Table 2, the 13 control items (which only appeared in the coursebook) were classified into two categories that distinguished their level of prominence or salience: low salience and low salience plus. As shown in Table 3, low-salience sequences are those occurring one to three times in meaningfocused input, but not in coursebook exercises. Low-salience plus sequences occurred two to six times in meaning-focused input, and in coursebook exercises. These two types of control items were compared to the explicitly taught items that occurred one to six times in meaning-focused input in the coursebook and were also explicitly taught in experimental sessions. Only the items that met these requirements were used for this analysis, which meant 12 out of the total 13 control items, and 42 out of the total 56 experimental items that the experimental groups (sentence-context, no-context) were exposed to.

Table 3

Target Items Classified by Salience

\begin{tabular}{lrrrr}
\hline & $\begin{array}{r}\text { Numbers } \\
\text { of items }\end{array}$ & $\begin{array}{r}\text { Frequency of exposure in } \\
\text { meaning-focused input }\end{array}$ & Exercises & $\begin{array}{r}\text { Explicit } \\
\text { teaching }\end{array}$ \\
\hline Low-salience & 7 & $1-3$ & No & No \\
Low-salience plus & 5 & $2-6$ & Yes & No \\
Explicitly taught & 42 & $1-6$ & No & Yes \\
\hline
\end{tabular}

To examine the possible effect of the prominence the same formulaic sequences were given in the coursebook on their learning in the control condition (the group that did not receive the explicit treatment), the 69 items appearing in the coursebook were classified by their salience in the coursebook activities. As illustrated in Table 4, low-salience sequences for the control group were encountered one to three times in the meaning-focused input, but not in exercises, similar to those for the experimental conditions. Low-salience plus items were encountered not only one to seven times in meaning-focused input, but in exercises as well. Fifty-four of the total 69 items that satisfied the requirements for this classification were chosen for the analysis.

Table 4

Target Items Classified by Salience for the Control Group

\begin{tabular}{lrrr}
\hline & Numbers of items & $\begin{array}{r}\text { Frequency of exposure in } \\
\text { meaning-focused input }\end{array}$ & Exercises \\
\hline Low-salience & 41 & $1-3$ & No \\
Low-salience plus & 13 & $1-7$ & Yes \\
\hline
\end{tabular}




\section{Context Sentences}

Participants in the sentence-context group were exposed to the 56 experimental items with sentence context. In an attempt to ensure contextual diversity so as to suit the preferences of different learners, sentences were selected from four sources: dictionaries (41.1\%), learning materials (14.3\%), BNC and Brown Written corpus (21.4\%), and BNC Spoken corpus (9.8\%). A total of 112 sentences were created. Each of the 56 experimental sequences, which were made salient by boldfacing or highlighting in the sentence, occurred once in each sentence. Thus, there were two different sentences for each experimental sequence. Each of the sentences was used twice over the whole experiment, that is, in Sessions 1 and 3, or in Sessions 2 and 4. Since the vocabulary level of the participants was at approximately 2,000 word families, the context sentences were analyzed and modified to the extent that more than $97 \%$ of the token coverage was from the most frequent BNC 2,000 word families. This was done because learners are recommended to know $95 \%$ or more of the words in a text to comprehend that text (Hu \& Nation, 2000; Laufer, 1989). The purpose of the analysis and the modification of the sentences was to ensure that the effects or lack of effect of the treatment were not due to the difficulty of the context sentences.

\section{Tests of Knowledge of Formulaic Sequences}

Two multiple-choice tests were created to measure the participants' knowledge of the 69 formulaic sequences identified as occurring in the coursebook. The items on these tests formed the basis of the pretests, posttests, and delayed posttests. The tests were administered in the same order and manner for all groups, although the test items were presented in a different order for each test. For multiple-choice items on both tests, distractors were created based on the procedure for creating vocabulary test items used by Nagy, Anderson, and Herman (1987). In this procedure, distractors are designed to be at different levels of difficulty. At the lowest level of difficulty, the meanings and the parts of speech of the distractors are as different from those of the target items as possible. At the intermediate level of difficulty, the parts of speech of the distractors are almost the same, but the meanings are considerably different. At the highest level of difficulty, the meanings represented by the distractors are similar to or closely associated with the meaning of the target word. The options for each test item were in the same order in all the tests.

The first test was the cloze test, which was created to measure learners' ability to recognize receptive knowledge of form and meaning of the sequences presented in sentence contexts. For each item, the participants were presented with an incomplete sentence and had to complete the gap with one out of the six forms provided (i.e., the correct formulaic sequence and five distractors). The sentences used in the test were adapted from those used in the experimental conditions. The sentences had to be modified to make sure that the words appearing before and after the gap fulfilled the grammatical 
and semantic constraints of the different options. This may have resulted in sentence contexts that were less frequent than those used in the learning conditions. However, in this testing context the priority was for all sentence contexts to meet the requirements of the options in a systematic way. An example of an item on this test is shown in Table 5.

Table 5

Example of an Item from the Cloze Test with Distractor Explanations

Stem: People join groups for motivation, learning, and support.

Options Distractor Explanation

\begin{tabular}{ll}
\hline A. on average & $\begin{array}{l}\text { Formulaic sequence taught in explicit sessions. Syntactically could occur } \\
\text { with the words before it in the sentence, but not the words after it. } \\
\text { B. all sorts of }\end{array}$ \\
$\begin{array}{l}\text { Correct answer. } \\
\text { C. variety with }\end{array}$ & $\begin{array}{l}\text { Variety similar in meaning to sorts. Meaning of variety with related to all } \\
\text { sorts of, but this word group did not fit syntactically in the sentence. }\end{array}$ \\
D. all the way & $\begin{array}{l}\text { Formulaic sequence occurring in both the PHRASE List and the } \\
\text { coursebook. Syntactically could occur with the words before it in the } \\
\text { sentence, but not the words after it. }\end{array}$ \\
E. find out & $\begin{array}{l}\text { Formulaic sequence occurring in both the PHRASE List and the } \\
\text { coursebook. Meaning could fit the sentence, but it does not fit syntactically } \\
\text { in the sentence. }\end{array}$ \\
F. and all that & $\begin{array}{l}\text { Formulaic sequence occurring in both the PHRASE List and the } \\
\text { coursebook. Selection was random. }\end{array}$ \\
\end{tabular}

The second test, the translation test, was used to measure form and meaning recognition of the target items without context. Participants were presented with the Vietnamese translations of the target items in isolation and had to match them to the correct English translation from a set of formulaic sequences provided. An example of an item on this test is shown in Table 6.

Table 6

Example of an Item from the Translation Test with Distractor Explanations

Stem: Nhiều, rất nhiều

Options Distractor explanation

\begin{tabular}{ll}
\hline A. large scale & $\begin{array}{l}\text { Formulaic sequence taught in explicit sessions. Semantically related to the } \\
\text { answer. }\end{array}$ \\
B. a couple of & $\begin{array}{l}\text { Formulaic sequence occurring in the PHRASE List. Partially } \\
\text { orthographically similar to the answer in Vietnamese. }\end{array}$ \\
C. more and more & $\begin{array}{l}\text { Formulaic sequence occurring in both the PHRASE List and the } \\
\text { coursebook. Semantically similar to the answer. }\end{array}$ \\
D. a great deal & $\begin{array}{l}\text { Correct answer. } \\
\text { E. a number of }\end{array}$ \\
$\begin{array}{l}\text { Formulaic sequence occurring in both the PHRASE List and the } \\
\text { coursebook. Partially orthographically similar to the answer. }\end{array}$ \\
F. extent of & $\begin{array}{l}\text { Extent was related in meaning with a great deal. Extent of partially } \\
\text { orthographically similar to the answer in Vietnamese. }\end{array}$ \\
\hline
\end{tabular}




\section{Procedure}

The language course consisted of 90 hours of classroom instruction, 3 hours per day, 5 days a week, over 6 weeks. For the experimental groups, the 90 hours of classroom instruction were divided into 2.67 hours of explicit teaching of formulaic sequences and 87.33 hours of traditional coursebook instruction. For the control group, the 90 hours of classroom was completely devoted to the traditional coursebook instruction, and the control group spent the time the experimental groups spent on formulaic sequence instruction on further work on the meaning-focused input in the textbook. Appendix B presents the overall teaching procedure for the three groups over the whole language course, exclusive of the weeks for the testing procedure. Table 7 presents the overall experimental procedure for the explicit teaching and testing of the experimental items. In the first week, the Vocabulary Levels Test and the formulaic sequence pretests were administered. To avoid the possible effects of one test on the other, the cloze test was administered first, followed by a 10-minute break before the translation test was administered. The order of the items on the first test differed from that of the second.

The target formulaic sequences were explicitly taught in four sessions in Weeks 2 through 5 of the study. The first researcher used PowerPoint slides to present the target items in the first two of these sessions. In the first teaching session, the form and meaning of the items were presented in the direction of L2 to L1 (English to Vietnamese). This was followed a paper-based matching exercise. For the no-context group, each formulaic sequence was presented with a word missing (e.g., $a \ldots$ deal). The researcher read the sequence and asked the participants to guess the missing word. If no correct response was immediately given, the researcher continued by providing the missing word with the letters presented in random order (e.g., a eragt deal), and asked the participants to once again try to supply the missing word. The full sequence was then presented (e.g., a great deal) with its translation. In the sentencecontext condition, the same procedure was carried out, but the sequence was presented in a full sentence. The same procedure was used for the second teaching session, but in the direction of L1 to L2. In the third and fourth teaching sessions, word cards with the English formulaic sequence on one side and the Vietnamese translation on the other were used for instruction purposes. For the sentence-context condition, a full sentence was included on both sides of the card. In the third session, the participants worked in pairs with the cards to recall the form and meaning in the direction of L2 to L1, and then made a short sentence for each item. In Session 4, a similar procedure was used but in the direction of L1 to L2. For each teaching session, the participants encountered each item twice. To avoid the possibility that the participants might revise the target items out of classroom, they were asked not to take notes during the treatment sessions, and they were not informed about the next teaching session or about the posttests. Overall, the time for explicit 
teaching over 4 weeks was 160 minutes, accounting for approximately 3.4\% of the total course time. In the sixth week, the posttests were administered in the same manner as the pretests, and 3 weeks later, the delayed posttests were administered.

Table 7

Experimental Procedure for Explicit Teaching of Formulaic Sequences Incorporated into the Language Program

\begin{tabular}{lllllll}
\hline Week 1 & Week 2 & Week 3 & Week 4 & Week 5 & Week 6 & Week 9 \\
\hline $\begin{array}{l}\text { VLT and } \\
\text { Pretests }\end{array}$ & Session 1 & Session 2 & Session 3 & Session 4 & Posttests & $\begin{array}{l}\text { Delayed } \\
\text { Posttests }\end{array}$ \\
100 minutes & 40 minutes & 40 minutes & 40 minutes & 40 minutes & 90 minutes & 90 minutes \\
\hline
\end{tabular}

Note. VLT $=$ Vocabulary Levels Test.

\section{Scoring and Analysis}

Dichotomous scoring was used for all test items. A correct answer received a score of one point, and an incorrect a score of zero. The statistical analyses were based on the mean scores of the items. Normal distribution of the mean scores of the two posttests (cloze and translation) in the three groups was checked, and a Shapiro-Wilk test showed that data were approximately distributed, as only one of the scores of the delayed translation test in the nocontext group was not normally distributed. All other mean posttest scores were normally distributed. The Levene's tests for equality of error variances showed that the mean posttest scores did not violate the assumption of homogeneity of variance, as the scores for all posttests were $\geq .05$. To answer the third research question, relative gains were used. This is because the preknowledge of the target items varied across the participants, and relative gains take into account the learning opportunities that vary amongst the participants (Webb \& Chang, 2015). Relative gains were calculated based on the following formula:

Relative gain $(\%)=($ posttest mean score - pretest mean score $) /$

(1- pretest mean score) $\times 100$

\section{Results and Discussion}

\section{Research Question 1: The Impact of Explicit Teaching}

In order to examine the impact of explicit instruction, the results from the control group (which was exposed to the target items in traditional coursebook instruction but received no explicit treatment) and the two experimental groups (i.e., sentence-context and no-context) were compared by means of ANCOVAs for the cloze and the translation posttests, where the dependent variable was the results of the posttest and the delayed posttest, and the co- 
variate the pretest score. As can be seen in Table 8, the three groups differed from each other significantly in all four comparisons, and the effect sizes were large. Least significant difference (LSD) post hoc tests revealed that, as expected, in all four cases the experimental groups learned significantly better than the control group (see Figure 1). Importantly, there was no significant difference between the two experimental conditions, that is, sentence-context and no-context groups.

\section{Table 8}

Analyses of Covariance of the Two Vocabulary Tests in the Post and Delayed Conditions with the Pretest Scores Being the Covariates

\begin{tabular}{|c|c|c|c|c|c|c|}
\hline & \multicolumn{3}{|c|}{$M(S D)$} & \multirow{2}{*}{\multicolumn{2}{|c|}{$\begin{array}{r}\text { Effect } \\
\text { size }^{a}\end{array}$}} & \multirow[b]{2}{*}{ Post-hoc ${ }^{b}$} \\
\hline & $\begin{array}{c}\text { Sentence- } \\
\text { context group } \\
\quad(n=19)\end{array}$ & $\begin{array}{c}\text { No-context } \\
\text { group } \\
(n=21) \\
\end{array}$ & $\begin{array}{l}\text { Control } \\
\text { group } \\
(n=20)\end{array}$ & & & \\
\hline Cloze posttest & $67 \%(0.18)$ & $63 \%(0.15)$ & $37 \%(0.09)$ & $29.92^{\star \star *}$ & .517 & $\mathrm{~S}, \mathrm{~N}>\mathrm{C}$ \\
\hline $\begin{array}{l}\text { Translation } \\
\text { posttest }\end{array}$ & $82 \%(0.14)$ & $84 \%(0.12)$ & $50 \%(0.10)$ & $59.34^{\star \star *}$ & 679 & $\mathrm{~S}, \mathrm{~N}>\mathrm{C}$ \\
\hline $\begin{array}{l}\text { Cloze delayed } \\
\text { posttest }\end{array}$ & $68 \%(0.19)$ & $64 \%(0.17)$ & $38 \%(0.11)$ & $22.28^{\star \star \star}$ & .443 & $\mathrm{~S}, \mathrm{~N}>\mathrm{C}$ \\
\hline $\begin{array}{l}\text { Translation } \\
\text { delayed posttest }\end{array}$ & $79 \%(0.13)$ & $83 \%(0.14)$ & $53 \%(0.08)$ & $43.66^{\star \star \star}$ & .609 & $\mathrm{~S}, \mathrm{~N}>\mathrm{C}$ \\
\hline
\end{tabular}

Note. $\mathrm{S}=$ Sentence-context group, $\mathrm{N}=$ No-context group, $\mathrm{C}=$ Control group.

aPartial Eta squared; 'bSD.

${ }^{* * *} p<.001$.

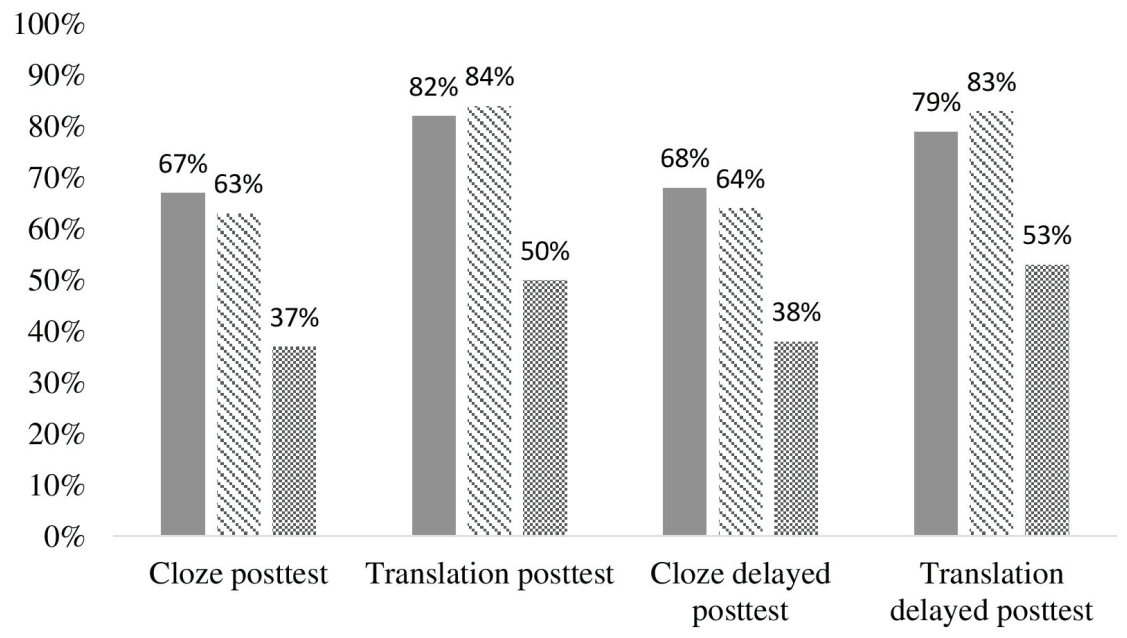

Sentence-context group $\times$ No-context group $\quad$ Control group

Figure 1: Vocabulary posttest (immediate and delayed) scores in the experimental and control groups. 
Thus, in answer to the first research question, the results not unexpectedly indicate that the incorporation of explicit teaching of formulaic sequences was more effective than relying only on the presentation of formulaic sequences using traditional coursebook instruction. Not only were the effect sizes large, but the delayed posttest showed that the significant learning gains remained stable over 3 weeks. The findings are in line with evidence on effects of explicit instruction on both single words (e.g., Laufer, 2006; Webb, 2005, 2007b) and formulaic sequences (e.g., Alali \& Schmitt, 2012; Peters, 2012, 2014; Webb \& Kagimoto, 2009, 2011). The findings were also consistent with those of Schmitt et al. (2004) regarding incorporating explicit instruction of formulaic sequences into a regular L2 course. This supports Dörnyei's (2009) claim that in instructed SLA, the explicit teaching of formulaic language is of crucial importance.

\section{Research Question 2: Differences Between the Two Experimental Conditions}

In answer to the second research question, contrary to expectations, the results reported above indicate that instruction with context sentences was not more effective than with no context for both test batteries. These nonsignificant findings echoed those obtained for individual words by Dempster (1987), Pickering (1982), and Webb (2007b). The findings also supported Griffin (1992) for low-proficiency participants, but this was not the case for advanced participants in that study, because the latter benefited from learning vocabulary with the sentence context. One explanation for this could be that when engaging in learning pairs of L1-L2 items with no context, the participants could have used their own strategies to generate mental context and associations, processing them deeply to commit into memory rather than applying shallow processing of simple rehearsal (Laufer \& Shmueli, 1997).

Another possible explanation is that the participants in the present study were at a low proficiency level. As such, their second language knowledge might be insufficient to take advantage of syntactic and semantic associations presented in the context sentences so as to learn the target formulaic sequences better. According to Nation and Coady (1988), this is because second language learners who have weak vocabulary tend to be poor decoders, and they therefore do not seem to be in a position to make use of the context, despite the context being within their level of knowledge.

\section{Research Question 3: The Impact of Degree of Salience of Formulaic Sequences Embedded in Traditional Coursebook Instruction}

In order to answer the third research question, vocabulary scores for those items that had appeared in the coursebook in different types of activities and input modes were analyzed and compared with the items that had been explicitly taught in the experimental sessions. A repeated measures ANOVA with gain score as the dependent variable and type of exposure as the independent variable was performed. Table 9 presents a comparison of the gain scores 


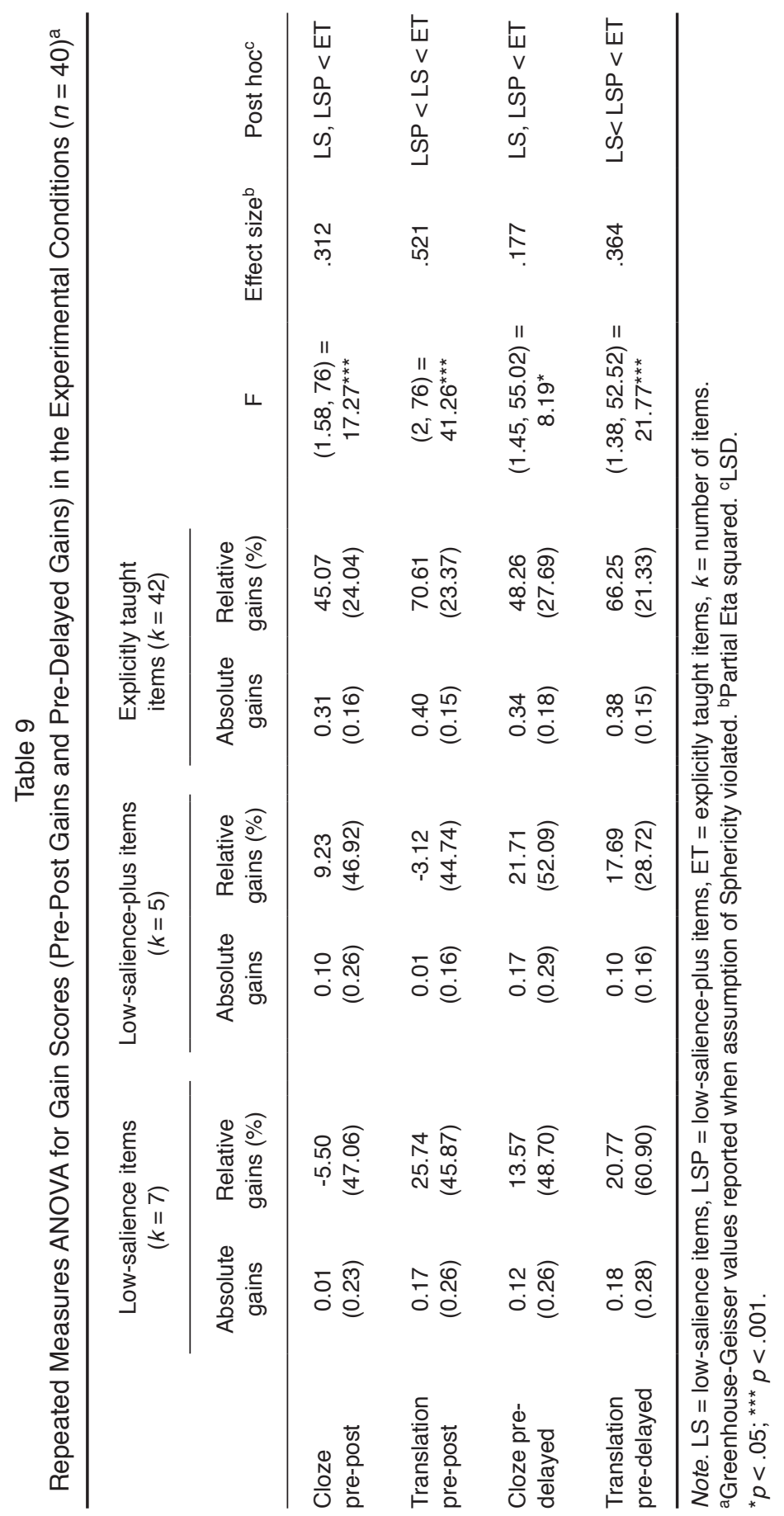


of the two groups of target items-low-salience and low-salience-plus - that received no explicit teaching in the experimental groups. The table shows a very consistent pattern: the explicitly taught items were always learned significantly better than the non-explicitly-taught items, regardless of whether the latter belonged to the low-salience or the low-salience-plus categories. Furthermore, the low-salience-plus items did not score any higher than the low-salience ones (indeed, in one instance the low-salience-plus score was lower than that of the low-salience group). This presents a bleak picture of the effectiveness of the teaching of formulaic sequences as part of vocabulary activities within traditional coursebook instruction: items that were targeted by special exercises did not do better than items that were only presented in meaningful input, without being targeted in special exercises, and neither category got even close to the impact of the experimental conditions.

Table 9 presented results from the experimental groups, which received both types of treatment, and one could argue that the reason the non-explicitly taught items were not learned well is that the students' attention was drawn to the explicitly taught items. Therefore, further analyses were conducted in the control group, where there was no possible distraction by explicit teaching. Table 10 presents the results of paired sample $t$-tests comparing the gain scores of low-salience and low-salience-plus items. As can be seen in the table, no significant difference emerged in any of the testing conditions.

Table 10

Paired Sample $t$-Tests of Gain Scores (Pre-Post Gains and Pre-Delayed Gains) in the Control Condition $(n=20)$

\begin{tabular}{|c|c|c|c|c|c|}
\hline & \multicolumn{2}{|c|}{ Low-salience items $(k=41)$} & \multicolumn{2}{|c|}{ Low-salience-plus items $(k=13)$} & \multirow[b]{2}{*}{$t(19)$} \\
\hline & $\begin{array}{l}\text { Absolute } \\
\text { gains }\end{array}$ & $\begin{array}{l}\text { Relative } \\
\text { gains (\%) }\end{array}$ & $\begin{array}{c}\text { Absolute } \\
\text { gains }\end{array}$ & $\begin{array}{l}\text { Relative } \\
\text { gains (\%) }\end{array}$ & \\
\hline Cloze pre-post & $\begin{array}{c}0.07 \\
(0.13)\end{array}$ & $\begin{array}{c}8.63 \\
(17.89)\end{array}$ & $\begin{array}{c}0.07 \\
(0.21)\end{array}$ & $\begin{array}{c}9.65 \\
(33.97)\end{array}$ & -.14 \\
\hline $\begin{array}{l}\text { Translation } \\
\text { pre-post }\end{array}$ & $\begin{array}{c}0.03 \\
(0.11)\end{array}$ & $\begin{array}{c}4.56 \\
(17.29)\end{array}$ & $\begin{array}{l}-0.04 \\
(0.18)\end{array}$ & $\begin{array}{l}-24.15 \\
(72.12)\end{array}$ & 1.77 \\
\hline $\begin{array}{l}\text { Cloze } \\
\text { pre-delayed }\end{array}$ & $\begin{array}{c}0.09 \\
(0.14)\end{array}$ & $\begin{array}{c}12.07 \\
(18.63)\end{array}$ & $\begin{array}{c}0.15 \\
(0.17)\end{array}$ & $\begin{array}{l}24.34 \\
(28.64)\end{array}$ & -1.77 \\
\hline $\begin{array}{l}\text { Translation } \\
\text { pre-delayed }\end{array}$ & $\begin{array}{c}0.08 \\
(0.91)\end{array}$ & $\begin{array}{c}12.73 \\
(14.21)\end{array}$ & $\begin{array}{c}0.00 \\
(0.20)\end{array}$ & $\begin{array}{l}-18.30 \\
(82.13)\end{array}$ & 1.79 \\
\hline
\end{tabular}

Note. $k=$ number of items.

Thus, Tables 9 and 10 show that the formulaic sequences that occurred in vocabulary-teaching exercises in the coursebook - that is, the low-salienceplus items-were not learned significantly better than those that only occurred in the input texts of the coursebook without being included in specific exercises (i.e., low-salience items). This is again a rather sobering indication of 
the inefficiency of vocabulary instruction in the specific learning environment of the study. To confirm the absence of any learning gains in this respect, a final analysis has been carried out in which the "plus factor" (i.e., the additional learning impact of the items being included in exercises) was compared to the results obtained in the experimental groups and the control group.

The "plus factor" was operationalized by taking the pre-post difference between the low-salience-plus and low-salience items, thereby examining whether low-salience-plus items achieved a higher gain between the pretest and the posttest than the low-salience items (which lacked any occurrences in specific vocabulary-teaching coursebook exercises); for example, if a student improved by an average of .60 points in the salient-plus items between the pretest and the posttest, and only .50 in the salient items, his/her "plus factor" score was .10. The cloze test results did not show any significant differences in the "plus factor" between the experimental groups $(M=14.73, S D=67.20)$ and the control group $(M=1.27, S D=32.29), t(57)=.84, p=.40$. Similarly, no differences were found in the cloze pre- and delayed posttest (experimental conditions: $M=8.14, S D=69.85$; control condition: $M=9.49, S D=33.15), t(57)$ $=-0.82, p=.93$, the translation pre- and posttest (experimental conditions: $M$ $=-28.86, S D=57.09$; control condition: $M=-32.64, S D=99.86), t(57)=.18, p=$ .85 , and the translation pre- and delayed posttest (experimental conditions: $M=-3.08, S D=61.22$; control condition: $M=-31.88, S D=113.30), t(57)=1.27$, $p=.21$. In other words, the nonsignificant gain pattern characterizing lowsalience and low-salience-plus items was observable across all the teaching and assessment conditions.

To summarize the answer to the third research question, the results indicate that the degree of any form of salience of formulaic sequences in the traditional coursebook instruction appeared to have no effects on learning gains. Explicit teaching, however, was superior even to the most direct form of vocabulary instruction; that is, in contrast to the fact that adding a direct element to the teaching of vocabulary items in traditional coursebook instruction (by means of vocabulary exercises) was not more effective than presenting the vocabulary items in meaningful input in the coursebook, complementing meaning-focused tasks with explicit teaching in the experimental condition resulted in significantly more learning. This effectiveness remained stable over 3 weeks, and the effect sizes were large for both testing times. The findings support the arguments by Dörnyei (2009, pp. 283-284) that although explicit learning is assumed to scaffold incidental learning in general, its impact in a language teaching program is contingent on how the target items are made salient, how they are presented, and how they are integrated with the indirect, meaning-focused (i.e., incidental) learning of that program. The explicit teaching component in the present study took these factors into consideration by employing a procedure of systematic instruction that created opportunities for the target items to be noticed, repeated, and retrieved. The significant gains achieved in the experimental conditions are 
all the more meaningful as the explicit teaching tasks were conducted only over four sessions, making up only $3.4 \%$ of the total course time, and thus it hardly interfered with the overall language teaching syllabus.

\section{Limitations and Further Research}

There are several limitations in the present study. First, the study was carried out in a 6-week EFL program, and the participants were low-proficiency students at a technology university. Therefore, any generalization that may be inferred from the study is limited to this context. Second, the tests used in the present study only measured receptive knowledge of form and meaning of the formulaic sequences because the participants were at a low proficiency level. Future research should consider tests that measure other aspects of knowledge of formulaic sequences. Third, to maintain pedagogical relevance, interlexical factors (e.g., congruency; cf. Peters, 2014) and intralexical factors (i.e., pronounceability, orthography, morphology, synformy, part of speech, and other semantic features; Laufer, 1997) that might affect learning of target formulaic sequences were not taken into consideration. Fourth, even though the tasks for explicit instruction in the present study were created to encourage the participants to process the context sentences, whether they wanted to do this or were able to do this seemed to be conditional on individual differences. For example, given that advanced learners may have their own strategies to take advantage of context sentences while learning words (Griffin, 1992), it would be useful to know whether higher proficiency learners would read, analyze, or process the context sentences so that they would learn formulaic sequences with context better than without. Finally, during the explicit learning of the target items with context sentences, the participants could have attended to learning the form-meaning link rather than to this context assistance. Griffin (1992) suggested that context sentences may give rise to the syntactic and semantic processing once the task of learning them is taken as a semantic task (i.e., learning contextual meaning) rather than as an episodic task (i.e., recalling word pairs). With the former task, learners can engage with contextual information that may support explicit learning of target items and leading to better learning. Thus, further research may consider designing tasks that can motivate learners to utilize this.

\section{Pedagogical Implications}

The findings of the present study suggest a number of useful implications for teachers, curriculum designers, and coursebook writers. To begin with, the findings support explicit teaching and its advantage over vocabulary learning through traditional coursebook instruction regarding learning of the receptive form and meaning of formulaic sequences. Thus, it is important that teaching professionals consider integrating explicit teaching of formulaic sequences into their language classes. This is because although formulaic sequences may occur in exercises and meaning-focused tasks of coursebooks, 
they are unlikely to be learned if they are not explicitly taught. To make explicit teaching a success in the classroom, teachers and curriculum designers can plan and carry out their teaching practices and syllabuses in an organized fashion. For example, in the procedure of the present study, three main factors (among others) were taken into account. First, the items selected were useful and befitting to the proficiency level of the learners (i.e., they co-occurred both in the coursebook and in a frequency list targeted to a proficiency level similar to that of the learners). Second, the instruction was carried out in stand-alone sessions instead of being part of meaning-focused activities. Third, the procedure ensured that the target items were attended to, repeated, and retrieved at weekly intervals.

Furthermore, because the findings indicate no significant differences in learning gains between teaching frequent formulaic sequences with or without sentence context, teaching professionals-dependent on their teaching motivation-may decide to either include or exclude context sentences in their instruction. If contextualized teaching is preferred, the sentence context should be comprehensible to the learners. It is thus important to take into consideration the proficiency of the learners when it comes to selecting the context sentences. For instance, with the participants' vocabulary level taken into consideration, more than $97 \%$ of the coverage of the context sentences used in the study was from the most frequent 2,000 word families.

Finally, the results indicate no effect of degree of salience of the formulaic sequences in the coursebook input or vocabulary activities on learning of the target sequences. Thus, to help incidental learning of target formulaic sequences through meaning-focused tasks, coursebook designers may consider integrating guidelines for explicit teaching of these items into teacher manuals. Also, exercises that teach formulaic language should be embedded into coursebooks in a way that the sequences spread systematically across several lessons instead of occurring in one or a few exercises in isolation, before or after meaning-focused tasks, as was the case in the coursebook investigated. The integration of explicit teaching and vocabulary exercises should ensure that target items are repeated and retrieved at least eight times in spaced intervals.

\section{Conclusion}

This study set out to investigate how best to teach formulaic sequences in language classes. To address this, we attempted to respond to the call for research in instructed SLA to maximize the effectiveness of explicit and incidental learning in tandem (cf. Dörnyei, 2013). The findings suggest that the incorporation of systematic explicit teaching elements into a traditional language syllabus is more effective than following the procedures of traditional coursebook instruction and their approach to vocabulary instruction for the purposes of learning formulaic sequences. The fact that learning through a 
combination of explicit instruction and incidental encounters was significantly more effective than what was considered to be the best vocabulary teaching approach in the instructional context in question (i.e., coursebookbased exercises accompanied by incidental encounters in meaning-focused tasks) indicates that it is important to consider what type of explicit exposure is more effective in a particular context, and how explicit exposure can work with incidental encounters to benefit learning. The other result of this study was that there was no significant difference between learning the frequent formulaic sequences with or without context sentences. The reason, amongst others, could be that the participants were insufficiently motivated to be engaged in the tasks designed for learning with context to make use of their contextual meanings. Above all, the study has contributed to our understanding of the teaching of EFL, and it has shown not only that explicit teaching seems to be effective for formulaic language learning, but also which types of explicit instruction seem to be most beneficial.

\section{Note}

1 Traditional coursebook instruction is operationalized in this article as the teaching method that exclusively relies on the materials and activities included in the coursebook. These include meaning-focused input (reading texts, listening texts, instructions for tasks, etc.) and vocabulary activities that occasionally include formulaic sequences, without formulaic language being the main focus of instruction. This approach is contrasted with the explicit teaching approach that consists of teaching through exercises specifically designed to teach a set of formulaic sequences.

\section{Authors}

Duyen Le-Thi works at FPT University Vietnam. She is currently a PhD student at the University of Nottingham. Her research includes instructed acquisition of formulaic sequences and the use of motivational techniques to improve effectiveness of teaching and learning formulaic sequences. Her research interests involve L2 motivation and vocabulary acquisition.

Michael P. H. Rodgers is an Assistant Professor in the School of Linguistics and Language Studies at Carleton University. His research interests include vocabulary acquisition, formulaic language learning, language learning through viewing television, and extensive viewing and listening.

Ana Pellicer-Sánchez is a Senior Lecturer in Applied Linguistics and TESOL at the UCL (University College London) Institute of Education. Her research interests include the effectiveness of different input modes on the acquisition of both single words and formulaic sequences, and the use of online measures of eye-tracking to investigate vocabulary learning.

\section{References}

Alali, F. A., \& Schmitt, N. (2012). Teaching formulaic sequences: The same as or different from teaching single words? TESOL Journal, 3(2), 153-180. http://dx.doi.org/10.1002/tesj.13

Al Hassan, L., \& Wood, D. (2015). The effectiveness of focused instruction of formulaic sequences in augmenting L2 learners' academic writing skills: A quantitative research study. Journal of English for Academic Purposes, 17, 51-62. https://doi.org/10.1016/j.jeap2015.02.001

Biber, D., Conrad, S., \& Cortes, V. (2003). Lexical bundles in speech and writing: An initial taxonomy. In A. Wilson, P. Rayson, \& T. McEnery (Eds.), Corpus linguistics by the Lune: A festschrift for Geoffrey Leech (pp. 71-92). Frankfurt/Main, Germany: Peter Lang. 
Boers, F., Eyckmans, J., Kappel, J., Stengers, H., \& Demecheleer, M. (2006). Formulaic sequences and perceived oral proficiency: Putting a lexical approach to the test. Language Teaching Research, 10(3), 245-261. https://doi.org/10.1191/13621688061r195oa

Conklin, K., \& Schmitt, N. (2008). Formulaic sequences: Are they processed more quickly than nonformulaic language by native and nonnative speakers? Applied Linguistics, 29(1), 72-89. https://doi.org/10.1093/applin/amm022

Coxhead, A. (2015). Replication research in pedagogical approaches to formulaic sequences: Jones \& Haywood (2004) and Alali \& Schmitt (2012). Language Teaching, 51(1), 1-11. https:// doi.org/10.1017/S0261444815000221

DeKeyser, R., \& Juffs, A. (2005). Cognitive considerations in L2 learning. In E. Hinkel (Ed.). Handbook of research in second language teaching and learning (pp. 437-454). Mahwah, NJ: Lawrence Erlbaum.

Dempster, F. N. (1987). Effects of variable encoding and spaced presentations on vocabulary learning. Journal of Educational Psychology, 79(2), 162-170. http://dx.doi.org/10.1037/00220663.79.2.162

Dörnyei, Z. (2009). The psychology of second language acquisition. Oxford, UK: Oxford University Press.

Dörnyei, Z. (2013). Communicative language teaching in the twenty-first century: The 'principled communicative approach.' In J. Arnold \& T. Murphey (Eds.), Meaningful action: Earl Stevick's influence on language teaching (pp. 161-171). Cambridge, UK: Cambridge University Press.

Durrant, P., \& Schmitt, N. (2009). To what extent do native and non-native writers make use of collocations? IRAL - International Review of Applied Linguistics in Language Teaching, 47(2), 157-177. https://doi.org/10.1515/iral.2009.007

Durrant, P., \& Schmitt, N. (2010). Adult learners' retention of collocations from exposure. Second Language Research, 26(2), 163-188. https://doi.org/10.1177\%2F0267658309349431

Ellis, N. C. (1996). Sequencing in SLA: Phonological memory, chunking, and points of order. Studies in Second Language Acquisition, 18(1), 91-126. https://doi.org/10.1017/S0272263100014698

Ellis, N. C. (2002). Frequency effects in language processing: A review with implications for theories of implicit and explicit language acquisition. Studies in Second Language Acquisition, 24(2), 143-188. https://doi.org/10.1017/S0272263102002024

Ellis, N. C. (2012). Formulaic language and second language acquisition: Zipf and the phrasal teddy bear. Annual Review of Applied Linguistics, 32, 17-44. https://doi.org/10.1017/ S0267190512000025

Garnier, M., \& Schmitt, N. (2014). The PHaVE List: A pedagogical list of phrasal verbs and their most frequent meaning senses. Language Teaching Research, 19(6), 645-666. https://doi. org/10.1177/1362168814559798

Golonka, E., Bowles, A., Silbert, N., Kramasz, D., Blake, C., \& Buckwalter, T. (2015). The role of context and cognitive effort in vocabulary learning: A study of intermediate level learners of Arabic. Modern Language Journal, 99(1), 19-39. http://dx.doi.org/10.1111/modl.12191

González-Fernández, B., \& Schmitt, N. (2015). How much collocation knowledge do L2 learners have?: The effects of frequency and amount of exposure. ITL International Journal of Applied Linguistics, 166(1), 94-126. https://doi.org/10.1075/itl.166.1.03fer

Granger, S. (1998). Prefabricated patterns in advanced EFL writing: Collocations and lexical phrases. In A. Cowie (Ed.), Phraseology: Theory, analysis and applications (pp. 145-160). Oxford, UK: Oxford University Press.

Griffin, G. F. (1992). Aspects of the psychology of second language vocabulary list learning (Unpublished doctoral dissertation). University of Warwick, UK.

Hu, M., \& Nation, P. (2000). Unknown vocabulary density and reading comprehension. Reading in a Foreign Language, 13(1), 403-430.

Jones, M., \& Haywood, S. (2004). Facilitating the acquisition of formulaic sequences: An exploratory study in an EAP context. In N. Schmitt (Ed.). Formulaic sequences: Acquisition, processing and use (pp. 269-300). Amsterdam, Netherlands: John Benjamins. 
Koosha, M., \& Jafarpour, A. A. (2006). Data-driven learning and teaching collocation of prepositions: The case of Iranian EFL adult learners. Asian EFL Journal, 8(4), 192-209.

Kremmel, B., Brunfaut, T., \& Alderson, J. C. (2015). Exploring the role of phraseological knowledge in foreign language reading. Applied Linguistics, 38(6), 848-870. https://doi.org/10.1093/ applin/amv070

Laufer, B. (1989). What percentage of text-lexis is essential for comprehension? In C. Lauren \& M. Nordman (Eds.), Special language: From humans to thinking machines (pp. 316-323). Clevedon, UK: Multilingual Matters.

Laufer, B. (1997). The lexical plight in second language reading: Words you don't know, words you think you know, and words you can't guess. In J. Coady and T. Huckin (Eds.), Second language vocabulary acquisition: A rationale for pedagogy (pp. 20-34). Cambridge, UK: Cambridge University Press.

Laufer, B. (2006). Comparing focus on form and focus on forms in second-language vocabulary learning. Canadian Modern Language Review, 63(1), 149-166. https://doi.org/10.1353/ $\mathrm{cml} .2006 .0047$

Laufer, B., \& Girsai, N. (2008). Form-focused instruction in second language vocabulary learning: A case for contrastive analysis and translation. Applied Linguistics, 29(4), 694-716. https://doi. org/10.1093/applin/amn018

Laufer, B., \& Rozovski-Roitblat, B. (2011). Incidental vocabulary acquisition: The effects of task type, word occurrence and their combination. Language Teaching Research, 15(4), 391-411. https://doi.org/10.1177/1362168811412019

Laufer, B., \& Shmueli, K. (1997). Memorizing new words: Does teaching have anything to do with it? RELC Journal, 28(1), 89-108. https://doi.org/10.1177/003368829702800106

Macis, M., \& Schmitt, N. (2016). The figurative and polysemous nature of collocations and their place in ELT. ELT Journal, 71(1), 50-59. https://doi.org/10.1093/elt/ccw044

Manage [Def. 1]. (n.d.). In Cambridge Dictionary. Retrieved from https://dictionary.cambridge.org/ dictionary/english/manage

Martinez, R., \& Schmitt, N. (2012). A phrasal expressions list. Applied Linguistics, 33(3), 299-320. https://doi.org/10.1093/applin/ams010

Nagy, W. E., \& Anderson, R. C. (1984). How many words are there in printed school English? Reading Research Quarterly, 19(3), 304-330. https://doi.org/10.2307/747823

Nagy, W. E., Anderson, R. C., \& Herman, P. A. (1987). Learning word meanings from context during normal reading. American Educational Research Journal, 24(2), 237-270. https://doi. org/10.3102/00028312024002237

Nakata, T. (2016). Does repeated practice make perfect? The effects of within-session repeated retrieval on second language vocabulary learning. Studies in Second Language Acquisition, 39(4), 653-679. https://doi.org/10.1017/S0272263116000280

Nation, I.S.P. (2013). Learning vocabulary in another language. Cambridge, UK: Cambridge University Press. https://doi.org/10.1017/CBO9781139524759

Nation, P., \& Coady, J. (1988). Vocabulary and reading. In R. Carter \& M. McCarthy (Eds.), Vocabulary and language teaching (pp. 97-110). London, UK: Longman.

Nation, P., \& Newton, J. (1997). Teaching vocabulary. In J. Coady \& T. Huckin (Eds.). Second language vocabulary acquisition: A rationale for pedagogy (pp. 238-254). Cambridge, UK: Cambridge University Press.

Nattinger, J. R., \& DeCarrico, J. S. (1992). Lexical phrases and language teaching. Oxford: Oxford University Press.

Paquot, M., \& Granger, S. (2012). Formulaic language in learner corpora. Annual Review of Applied Linguistics, 32, 130-149. https://doi.org/10.1017/S0267190512000098

Pawley, A., \& Syder, F.H. (1983). Two puzzles for linguistic theory: Nativelike selection and nativelike fluency. In J. C. Richards \& R.W. Schmidt (Eds.), Language and communication (pp. 191-225). London, UK: Longman.

Pellicer-Sánchez, A. (2016). Incidental L2 vocabulary acquisition from and while reading: An eye- 
tracking study. Studies in Second Language Acquisition, 38(1), 97-130. https://doi.org/10.1017/ S0272263115000224

Pellicer-Sánchez, A. (2017). Learning L2 collocations incidentally from reading. Language Teaching Research, 21(3), 381-402. https://doi.org/10.1177/1362168815618428

Pellicer-Sánchez, A., \& Schmitt, N. (2010). Incidental vocabulary acquisition from an authentic novel: Do things fall apart? Reading in a Foreign Language, 22(1), 31-55.

Peters, E. (2012). Learning German formulaic sequences: The effect of two attention-drawing techniques, Language Learning Journal, 40, 65-79. https://doi.org/10.1080/09571736.2012.658 224

Peters, E. (2014). The effects of repetition and time of post-test administration on EFL learners' form recall of single words and collocations. Language Teaching Research, 18(1), 75-94. https:// doi.org/10.1177/1362168813505384

Pickering, M. (1982). Context-free and context-dependent vocabulary learning: An experiment. System, 10(1), 79-83. https://doi.org/10.1016/0346-251X(81)90070-1

Saslow, J., \& Ascher, A. (2006). Summit 2. Harlow, UK: Pearson Longman.

Schmitt, N. (2000). Vocabulary in language teaching. Cambridge, UK: Cambridge University Press.

Schmitt, N. (2008). Instructed second language vocabulary learning. Language Teaching Research, 12(3), 329-363. https://doi.org/10.1177/1362168808089921

Schmitt, N. (2010). Researching vocabulary: A vocabulary research manual. London, UK: Palgrave Press.

Schmitt, N., \& Carter, R. (2004). Formulaic sequences in action: An introduction. In N. Schmitt (Ed.) Formulaic sequences: Acquisition, processing and use (pp. 1-22). Amsterdam, Netherlands: John Benjamins.

Schmitt, N., Dörnyei, Z., Adolphs, S., \& Durow, V. (2004). Knowledge and acquisition of formulaic sequences: A longitudinal study. In N. Schmitt (Ed.). Formulaic sequences: Acquisition, processing, and use (pp. 55-86). Amsterdam, Netherlands: John Benjamins.

Schmitt, N., Jiang, X., \& Grabe, W. (2011). The percentage of words known in a text and reading comprehension. Modern Language Journal, 95(1), 26-43. https://doi.org/10.1111/j.15404781.2011.01146.x

Schmitt, N., Schmitt, D., \& Clapham, C. (2001). Developing and exploring the behaviour of two new versions of the Vocabulary Levels Test. Language Testing, 18(1), 55-88. https://doi. org $/ 10.1177 / 026553220101800103$

Seibert, L. C. (1930). An experiment on the relative efficiency of studying French vocabulary in associated pairs versus studying French vocabulary in context. Journal of Educational Psychology, 21, 297-314. https://doi.org/10.1037/h0070517

Simpson-Vlach, R., \& Ellis, N. C. (2010). An academic formulas list: New methods in phraseology research. Applied Linguistics, 31(4), 487-512. https://doi.org/10.1093/applin/amp058

Sinclair, J. M. (1991). Corpus, concordance, collocation. Oxford, UK: Oxford University Press.

Siyanova, A., \& Schmitt, N. (2008). L2 learner production and processing of collocation: A multistudy perspective. Canadian Modern Language Review, 64(3), 429-458. https://doi.org/10.3138/ cmlr.64.3.429

Spöttl, C., \& McCarthy, M. (2004). Comparing knowledge of formulaic sequences across L1, L2, L3, and L4. In N. Schmitt (Ed.), Formulaic sequences: Acquisition, processing, and use (pp. 191-225). Amsterdam, Netherlands: John Benjamins.

Taylor, C. V. (1982). Vocabulary for education in English. World Englishes, 2(2), 100-104. https:// doi.org/10.1111/j.1467-971X.1982.tb00531.x

Van Zeeland, H., \& Schmitt, N. (2013). Incidental vocabulary acquisition through L2 listening: A dimensions approach. System, 41(3), 609-624. https://doi.org/10.1016/j.system.2013.07.012

Vidal, K. (2011). A comparison of the effects of reading and listening on incidental vocabulary acquisition. Language Learning, 61(1), 219-258. doi:10.1111/j.1467-9922.2010.00593.x

Waring, R., \& Takaki, M. (2003). At what rate do learners learn and retain new vocabulary from reading a graded reader? Reading in a Foreign Language, 15(2), 130-163. 
Webb, S. (2005). Receptive and productive vocabulary learning: The effects of reading and writing on word knowledge. Studies in Second Language Acquisition, 27(1), 33-52. https://doi. org/10.1017/S0272263105050023

Webb, S. (2007a). The effects of repetition on vocabulary knowledge. Applied Linguistics, 28(1), 46-65. https://doi.org/10.1093/applin/aml048

Webb, S. (2007b). Learning word pairs and glossed sentences: The effects of a single context on vocabulary knowledge. Language Teaching Research, 11(1), 63-81. https://doi. org/10.1177/1362168806072463

Webb, S., \& Chang, A. (2015). How does prior word knowledge affect vocabulary learning progress in an extensive reading program? Studies in Second Language Acquisition, 37(4), 651-675. https://doi.org/10.1017/S0272263114000606

Webb, S., \& Kagimoto, E. (2009). The effects of vocabulary learning on collocation and meaning. TESOL Quarterly, 43(1), 55-77. https://doi.org/10.1002/j.1545-7249.2009.tb00227.x

Webb, S., \& Kagimoto, E. (2011). Learning collocations: Do the number of collocates, position of the node word, and synonymy affect learning? Applied Linguistics, 32(3), 259-276. https://doi. org/10.1093/applin/amq051

Webb, S., Newton, J., \& Chang, A. (2013). Incidental learning of collocation. Language Learning, 63(1), 91-120. https://doi.org/10.1111/j.1467-9922.2012.00729.x

Webb, S., \& Rodgers, M. P. H. (2009a). The lexical coverage of movies. Applied Linguistics, 30(3), 407-427. https://doi.org/10.1093/applin/amp010

Webb, S., \& Rodgers, M. P. H. (2009b). Vocabulary demands of television programs. Language Learning, 59(2), 335-366. https://doi.org/10.1111/j.1467-9922.2009.00509.x

Wood, D. (2002). Formulaic language acquisition and production: Implications for teaching. TESL Canada Journal, 20(1), 1-15. https://doi.org/10.18806/tesl.v20i1.935

Wood, D. (2006). Uses and functions of formulaic sequences in second language speech: An exploration of the foundations of fluency. Canadian Modern Language Review, 63(1), 13-33. https://doi.org/10.1353/cml.2006.0051

Wray, A. (2002). Formulaic language and the lexicon. Cambridge, UK: Cambridge University Press.

Yamashita, J., \& Jiang, N. (2010). L1 influence on the acquisition of L2 collocation: Japanese ESL users and EFL learners acquiring English collocations. TESOL Quarterly, 44(4), 647-668. https://doi.org/10.5054/tq.2010.235998

Zyzik, E. (2011). Second language idiom learning: The effects of lexical knowledge and pedagogical sequencing. Language Teaching Research, 15(4), 313-433. https://doi.org/10.1177/ 1362168811412025

\section{Appendix A. Formulaic Sequences and Their Frequency of Occurrence in the Coursebook}

\begin{tabular}{|c|c|c|c|c|c|}
\hline & $\begin{array}{l}\text { Frequency } \\
\text { of } \\
\text { incidental } \\
\text { exposure } \\
\text { in } \\
\text { coursebook } \\
\text { input }\end{array}$ & $\begin{array}{c}\text { Frequency } \\
\text { of } \\
\text { explicit } \\
\text { exposure } \\
\text { in exercises }\end{array}$ & & $\begin{array}{l}\text { Frequency } \\
\text { of } \\
\text { incidental } \\
\text { exposure } \\
\text { in } \\
\text { coursebook } \\
\text { input }\end{array}$ & $\begin{array}{c}\text { Frequency } \\
\text { of } \\
\text { explicit } \\
\text { exposure } \\
\text { in exercises }\end{array}$ \\
\hline 1 account for & 1 & 0 & 6 consist of & 1 & 0 \\
\hline 2 all sorts of & 1 & 0 & 7 consistent with & 1 & 0 \\
\hline 3 as for & 1 & 0 & 8 from time to time & 1 & 0 \\
\hline 4 catch up & 1 & 0 & 9 in advance & 1 & 0 \\
\hline 5 common sense & 1 & 1 & 10 in common & 1 & 0 \\
\hline
\end{tabular}




\begin{tabular}{|c|c|c|c|c|c|}
\hline & $\begin{array}{l}\text { requency } \\
\text { of } \\
\text { ncidental } \\
\text { exposure } \\
\text { in } \\
\text { oursebook } \\
\text { input }\end{array}$ & $\begin{array}{c}\text { Frequency } \\
\text { of } \\
\text { explicit } \\
\text { exposure } \\
\text { in exercises }\end{array}$ & & $\begin{array}{l}\text { Frequency } \\
\text { of } \\
\text { incidental } \\
\text { exposure } \\
\text { in } \\
\text { coursebook } \\
\text { input }\end{array}$ & $\begin{array}{c}\text { Frequency } \\
\text { of } \\
\text { explicit } \\
\text { exposure } \\
\text { in exercises }\end{array}$ \\
\hline 11 in conjunction with & 1 & 0 & 41 appeal to & 3 & 0 \\
\hline 12 in particular & 1 & 0 & 42 go ahead & 3 & 0 \\
\hline 13 in spite of & 1 & 0 & 43 in case & 3 & 0 \\
\hline 14 in the first place & 1 & 0 & 44 in contrast & 3 & 0 \\
\hline 15 in time & 1 & 3 & 45 limited to & 3 & 0 \\
\hline 16 large scale & 1 & 0 & 46 put up with & 3 & 2 \\
\hline 17 look forward to & 1 & 0 & 47 when it comes to & 3 & 0 \\
\hline 18 no wonder & 1 & 0 & 48 after all & 4 & 0 \\
\hline 19 nothing but & 1 & 0 & 49 in need & 4 & 0 \\
\hline 20 on average & 1 & 0 & 50 it takes & 4 & 0 \\
\hline 21 take for granted & 1 & 0 & 51 tend to & 4 & 0 \\
\hline 22 take into account & 1 & 0 & 52 long term & 5 & 2 \\
\hline 23 that sort of thing & 1 & 0 & 53 make sense & 5 & 3 \\
\hline 24 the other day & 1 & 0 & 54 manage to & 5 & 0 \\
\hline 25 what if & 1 & 0 & 55 a great deal & 6 & 0 \\
\hline 26 as if & 2 & 0 & 56 bring about & 6 & 3 \\
\hline 27 at once & 2 & 0 & 57 fail to & 6 & 0 \\
\hline 28 even though & 2 & 3 & 58 followed by & 6 & 0 \\
\hline 29 happen to & 2 & 0 & 59 supposed to & 6 & 0 \\
\hline 30 in a way & 2 & 0 & 60 take up & 6 & 3 \\
\hline 31 in return & 2 & 0 & 61 as a result & 7 & 4 \\
\hline 32 key to & 2 & 0 & 62 carry out & 7 & 4 \\
\hline 33 no longer & 2 & 0 & 63 come up with & 7 & 5 \\
\hline 34 on the other hand & 2 & 2 & 64 in other words & 7 & 0 \\
\hline 35 point of view & 2 & 0 & 65 those who & 7 & 0 \\
\hline 36 provided that & 2 & 1 & 66 about to & 8 & 0 \\
\hline 37 rely on & 2 & 0 & 67 likely to & 8 & 0 \\
\hline 38 rid of & 2 & 0 & 68 rather than & 8 & 0 \\
\hline 39 short of & 2 & 0 & 69 lead to & 9 & 0 \\
\hline 40 turn up & 2 & 0 & & & \\
\hline
\end{tabular}


Appendix B. The Teaching Procedure for the Three Groups Over the Language Course

\begin{tabular}{|c|c|c|c|c|}
\hline Group & Week 2 & Week 3 & Week 4 & Week 5 \\
\hline $\begin{array}{l}\text { Sentence- } \\
\text { context }\end{array}$ & $\begin{array}{l}\text { Explicit teaching } \\
\text { of experimental } \\
\text { items with context } \\
\text { sentences }+ \\
\text { meaning-focused } \\
\text { coursebook input } \\
\text { and exercises }\end{array}$ & $\begin{array}{l}\text { Explicit teaching } \\
\text { of experimental } \\
\text { items with context } \\
\text { sentences }+ \\
\text { meaning-focused } \\
\text { coursebook input } \\
\text { and exercises }\end{array}$ & $\begin{array}{l}\text { Explicit teaching } \\
\text { of experimental } \\
\text { items with context } \\
\text { sentences }+ \\
\text { meaning-focused } \\
\text { coursebook input } \\
\text { and exercises }\end{array}$ & $\begin{array}{l}\text { Explicit teaching } \\
\text { of experimental } \\
\text { items with } \\
\text { context } \\
\text { sentences + } \\
\text { meaning-focused } \\
\text { coursebook input } \\
\text { and exercises }\end{array}$ \\
\hline No-context & $\begin{array}{l}\text { Explicit teaching } \\
\text { of experimental } \\
\text { items with } \\
\text { no context + } \\
\text { meaning-focused } \\
\text { coursebook input } \\
\text { and exercises }\end{array}$ & $\begin{array}{l}\text { Explicit teaching } \\
\text { of experimental } \\
\text { items with } \\
\text { no context + } \\
\text { meaning-focused } \\
\text { coursebook input } \\
\text { and exercises }\end{array}$ & $\begin{array}{l}\text { Explicit teaching } \\
\text { of experimental } \\
\text { items with } \\
\text { no context + } \\
\text { meaning-focused } \\
\text { coursebook input } \\
\text { and exercises }\end{array}$ & $\begin{array}{l}\text { Explicit teaching } \\
\text { of experimental } \\
\text { items with } \\
\text { no context + } \\
\text { meaning-focused } \\
\text { coursebook input } \\
\text { and exercises }\end{array}$ \\
\hline Control & $\begin{array}{l}\text { Regular } \\
\text { classroom } \\
\text { activities }+ \\
\text { meaning-focused } \\
\text { coursebook input } \\
\text { and exercises }\end{array}$ & $\begin{array}{l}\text { Regular } \\
\text { classroom } \\
\text { activities }+ \\
\text { meaning-focused } \\
\text { coursebook input } \\
\text { and exercises }\end{array}$ & $\begin{array}{l}\text { Regular } \\
\text { classroom } \\
\text { activities }+ \\
\text { meaning-focused } \\
\text { coursebook input } \\
\text { and exercises }\end{array}$ & $\begin{array}{l}\text { Regular } \\
\text { classroom } \\
\text { activities + } \\
\text { meaning-focused } \\
\text { coursebook input } \\
\text { and exercises }\end{array}$ \\
\hline
\end{tabular}

\section{Appendix C. Examples of the Occurrences of the Target Items come up with (Target Item \#63) and carry out (Target Item \#62) in the Coursebook Exercises (Saslow \& Ascher, 2006, pp. 114-115)}

B. Vocabulary. Phrasal verbs to discuss global issues.

Come up with: to think of an idea, plan, reply, etc.

They need to come up with a new plan to shelter the homeless.

Carry out: to do something that needs to be organized and planned.

It's time the president carried out her plan to vaccinate all school-age children.

C. There are seven errors with phrasal verbs in the article. Make corrections.

UN hunger relief

In order to assist local hospital in their battle against acute malnutrition, the UN World Food Program is carrying through operations in the southern region, where thousands of children have been going without proper food or sanitary conditions. The terrible hardship these children have had to put on with is the result of extreme 
poverty brought by ongoing drought conditions and the increasing number of people who have been recently laid away in the region because of factory closings. The poorest and most isolated families have run away of money to buy the staples they need to feed their children. The program has come down with a plan to provide emergency rations to these families.

D. Fill in the blanks with appropriate forms of phrasal verbs from the Vocabulary.

\section{Drug discovery plan to tap and help rain forests}

In Madagascar, off the coast of Africa, as farmers (1)...... usable land, they burn and destroy the rain forests to make more room for farming. If action is not taken, Madagascar's rain forests will soon be (2).......

A team of international scientists have (3)....... an interesting idea to help save the rain forests. Led by researcher Patricia Wright, they are currently negotiating agreements with local government officials to (4)...... research in the area through a program called "The Drug Discovery and Biodiversity Program." The program will study local traditional healing methods from scientific point of view. Researchers believe the rain forests of Madagascar may be home to sources of new drugs that will fight the numerous illnesses that millions of people (5)....... each year, such as malaria, AIDs and even the common cold. They are confident their plan will (6)....... much needed economic growth in the area.

Note. Underlining added to highlight the target items' use in the textbook. 